\title{
The history of the rice gene pool in Suriname: circulations of rice and people from the eighteenth century until late twentieth century
}

Harro MaAt and Tinde Van Andel

KEYWORDS: Atlantic slave trade, Suriname, African rice, Asian rice.

JEL CODES: F01, J61, N56, 013.

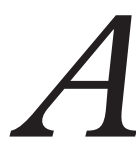
longside the trans-Atlantic slave trade, plant species travelled from Africa to the Americas and back. This article examines the emerging rice gene pool in Suriname due to the global circulation of people, plants and goods. We distinguish three phases of circulation, marked by two major transitions. Rice was brought to the Americas by European colonizers, mostly as food on board slave ships. In Suriname rice started off as a crop grown only by Maroon communities in the forests of the Suriname interior. For these runaway slaves cultivating several types of rice for diverse purposes played an important role in restoring some of their African culture. Rice was an anti-commodity that acted as a signal of protest against the slave-based plantation economy. After the end of slavery, contract labourers recruited from British India and the Dutch Indies also brought rice to Suriname. These groups grew rice as a commodity for internal and global markets. This formed the basis of a second transition, turning rice into an object of scientific research. The last phase of science-driven circulation of rice connected the late-colonial period with the global Green Revolution. 


\section{La historia del acervo genético del arroz en Surinam: la circulación de personas y arroz entre el siglo XVIII $\mathrm{y}$ finales del siglo $\mathrm{Xx}$}

\section{PALABRAS CLAVE: comercio atlántico de esclavos, Surinam, arroz africano, colonialismo.}

\section{CÓDIGOS JEL: F01, J61, N56, 013.}

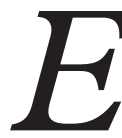
l comercio transatlantico de esclavos tuvo como consecuencia la transferencia de numerosas especies vegetales. Este artículo se centra en la aparición de un acervo genético del arroz en Surinam, como consecuencia del tráfico de personas, plantas y mercancías. Hemos dividido la historia de la circulación global del arroz en tres etapas, separadas por dos etapas transicionales. El arroz llegó a América de la mano de los colonizadores, que lo empleaban como alimento, especialmente a bordo de los navios que transportaban los esclavos. En Surinam no existían plantaciones de arroz, pero este cultivo pronto fue adoptado por grupos cimarrones formados por esclavos huidos hacia los bosques del interior de Surinam. El arroz parece haber jugado un papel fundamental para estos grupos, al permitirles restablecer algunos aspectos de su cultura africana ancestral, incluyendo el cultivo de distintas variedades de arroz. Como un símbolo de protesta contra las plantaciones con esclavos, el arroz cimarrón fue una antimercancía. Con el fin de la esclavitud llegaron a Surinam nuevos colectivos de trabajadores reclutados en las Indias británicas y holandesas. Estos grupos cultivaron arroz como una mercancía de primer orden. El artículo describe esta segunda transición, que convirtió este cereal en un objeto para la ciencia. Esta circulación de orientación científica conecta el periodo final colonial con la Revolución Verde.

Received: 2016-07-12 - Revised: 2017-06-01 - Accepted: 2017-06-06

Harro Maat [orcid.org/0000-0001-7338-7910] is a lecturer in Knowledge, Technology and Innovation, department of Social Sciences, Wageningen University. Address: P.O. Box 8130, 6700EW Wageningen (Netherlands). Email: Harro.Maat@wur.nl

Tinde van Andel [orcid.org/0000-0002-4951-1894] is Professor in Ethnobotany at Wageningen University and senior researcher at Naturalis Biodiversity Center. Address: P.O. Box 9517, 2300 RA Leiden (Netherlands). Email: tinde.vanandel@naturalis.nl 


\section{INTRODUCTION}

Rice is one of the crops introduced to the Americas and Caribbean through colonial trade routes. The first written accounts from the Spanish, about rice cultivation in Ecuador and Bolivia, as well as the early Portuguese documentation from Brazil date from the late sixteenth century (Pereira \& Guimarães, 2010). The introductions relate to cultivated species of rice, primarily Oryza sativa from Asia and more sporadically Oryza glaberrima from West Africa. Across the tropical zone of the Americas there are also wild populations of Oryza glumaepatula, Oryza latifolia, Oryza grandiglumis, and Oryza alta (Martínez et al., 2014), some of which were harvested as staple food by Native Americans (Hilbert et al., 2017). There is little doubt that European colonizers introduced rice to the Americas, but there is less clarity about the exact mode of transfer and motivations to do so in the early colonial period. One option is that, following the introduction of rice to southern Europe, the Spanish and Portuguese considered rice a valuable part of their diet and therefore brought it along to the Americas (Pereira \& Guimarães, 2010). For similar reasons rice was taken on board of slave ships, in particular when boarding slaves and provisions in the West African rice-growing zone. Some logs of slave ships have rice on the lists of victuals and there is evidence that the slave trade triggered the expansion of rice cultivation near slave ports along the West-African coast (Carney \& Rosomoff, 2009: 67; Mauser et al., 2015). The close connection between slavery and the emergence of rice production in the Americas is perhaps most apparent from the creation of rice plantations, most notably in area around Charles Town (Charleston) in South Carolina in the late seventeenth century and quickly expanding after a sudden increase in the demand for rice in Europe and America after 1730 (Smith, 2012; Coclanis, 1993). Similar slave-based rice plantations emerged in the Maranhaño region of Brazil somewhat later (Hawthorne, 2015).

This paper takes a closer look at rice in the Americas as an effect of global circulation. Rice cultivation in the Americas would not have existed without the creation of linkages between specific places elsewhere in the world, rich in different rice types ${ }^{1}$, and locations in the Americas where many different rice types accumulated into localised rice gene pools ${ }^{2}$. The focus of the paper is on the contributions of the Dutch to the emergence of rice gene pools in the Americas. The Dutch played a somewhat lesser but nevertheless influential role in the Atlantic slave trade and sold slaves to plantation owners in various set-

1. A rice type is used here as a general category referring to varieties of Asian rice (Oryza sativa) or African rice (Oryza glaberrima).

2. The term rice gene pool is used here as a general indicator for the total but changing set of rice varieties over different periods in a particular geographical region. 
tlements in South America and the Caribbean. About a quarter million slaves (see Table 1) were shipped to Suriname, a Dutch settlement bordering the northern tip of Brazil. The country lies between French Guiana at the east end and former British Guiana at the western border. After a series of wars and peace deals with the British, the Dutch gained control over the area in 1667 and started to develop the plantation economy in the years thereafter. After the abolition of slavery in 1863, the colonisers recruited labourers from Asia to work on the plantations. The African slaves and Asian indentured labourers shipped to the colony had a major impact on the population, social structures and economy of the country, including rice production.

We distinguish three historical periods, and two transitions connecting these periods, in the global circulation for rice in Suriname. The periods correspond with major historical events, the first period corresponds with the transatlantic slavery, in the eighteenth and nineteenth century, and the second period coincides with the transfer of indentured labourers from Asia, late nineteenth and early twentieth century. The third period corresponds with the emergence of scientific global networks for agriculture that formed the basis of the Green Revolution in the second half of the twentieth century. Each of these episodes had a major and lasting impact on the Surinamese society as a whole. They also had a major impact on rice cultivation, in terms of origins of rice varieties entering Suriname, the way rice was cultivated and what role the crop played in the economy of the country. In conceptual terms the first transition implied a shift from the circulation of rice as anti-commodity in the small Maroon communities to the circulation of rice as a commodity for national and international markets. The second transition implied that science rather than trade determined the circulation of different rice varieties. When using the term circulation, we imply the exchange of rice in interconnected and overlapping global and local or region-specific networks.

In the next section the forms of circulation and how this applies to the case of Suriname will be further explained. The paper then continues describing rice cultivation practices of the Maroons in Suriname and how they established a specific gene pool for rice. The sections thereafter discuss developments that followed the abolition of slavery in the nineteenth century. The Dutch stopped trading slaves as late as 1863 and in following decades tried to maintain the plantation economy in Suriname by transferring contract labourers from India and Indonesia. The recruitment of Indian labourers stopped in 1916, Javanese labour migration continued until 1939. These communities played an important role in the emergence of a commercial rice sector. From the late 1940s the Dutch increased the investments in commercial rice, including investments in plant breeding that, from the late 1960s, coincided with the Green Revolution. The history of the rice gene pool in Suriname, the paper concludes, is best understood as an effect of circulation of 
rice varieties in global and local networks, driven by a variety of forces of international, national and local actors.

\section{RICE, CIRCULATIONS AND TRANSITIONS}

What is known as the Middle Passage or triangular trade is probably one of the most vivid examples of circulation in global history. Ships leaving the ports of Europe with goods to be sold and exchanged for slaves on the African coast continued their journey to the Americas, where slaves were sold and products from the slave-based plantations and other goods were shipped back to Europe. The domination of European colonizers is generally explained by technical superiority, most notably guns and ships. However, these techniques become effective only in combination with other techniques, most notably navigation, that required not only capable persons to identify a ship's position but also map making and registration to return and use the same route repeatedly. In other words, the domination of European colonizers implied the creation of a global network of instruments, written documentation and well-trained people that allowed for long-distance control (Headrick, 1988; Law, 1986). The actor-networks created by scientists, sailors and soldiers formed the centres of wealth accumulation and colonial expansion.

The colonial networks not merely expanded into empty terrain but encountered local and sometimes equally sophisticated and powerful networks (Roberts, 2009). The implication of these encounters is that distinctions between colonial and indigenous require careful scrutiny and in some cases appeared hard to sustain due to the hybridization of knowledge, technologies and practices (Arnold, 2005). This perspective is useful for technologies as much as for goods and items that were transported across the globe to be sold as a commodity or taken on board as victuals or for other purposes. Things circulating across the globe received a meaning and were deemed fit for particular use as an effect of the cultures in the place of origin. Movement to other locations is possible by the expansion of networks into new places where encounters and connections with other networks changed the meaning and use, not rarely including physical transformation of the item.

For rice seeds and cultivation practices shipped to the Americas, the meanings and uses of seeds and cultivation practices is a combined effect of the connected and overlapping networks at the regions where they came from and were taken to. Important work in this respect is done by various historians who postulated the Black Rice thesis, pointing out that rice production in the Americas, in particular the successful rice plantations in Carolina, were only possible due to the seeds, knowledge and skills brought along by slaves 
(Carney, 2001; Fields-Black, 2008). African farmers, captured and sold as slaves to American colonizers, employed their expertise to the colonial rice plantations in the lowlands around Charleston and enabled the expansion of the rice plantations into other parts of South Carolina and Georgia ${ }^{3}$. Critics to the Black Rice thesis emphasize that the rice plantations in the Southern US and their commercial success was part of an economic system run by white planters who had much more influence on the course of action than African slaves.

Hawthorne (2015) provides further perspective to the issue by elaborating on the big difference between the cultural values of the cultivation systems and the social-economic networks in which rice-growing Africans were embedded on both sides of the Atlantic. Using the example of the Balanta in Upper Guinea, he explains how rice cultivation in Africa is embedded in community values and social relations that make the hard work in the rice fields meaningful, offering social rewards next to food and economic benefit. In contrast, the rice plantations in the Americas were part of a harsh regime that lacked any reward for growing rice by the slaves other than mere survival. In other words, the cultural significance of rice for people in West Africa gives reason to assume they brought it along to the Americas, but for the slaves the plantation regime was the only, unrewarding and unjust social structure for rice cultivation.

There is, however, one exception to the above picture. Slaves who ran away from plantations, not rarely after a revolt, created settlements in places out of reach for colonial authorities. These Maroon communities provide a new social context in which the people picked up their lives adjusted to the new conditions but relying on their African experiences. Agriculture received a new meaning in these communities and revived as a socially rewarding activity. These so-called Maroon cultures are present in the forest interior of Suriname until today. Rice is a major crop grown by the Suriname Maroons. The Scottish mercenary John Stedman, hired by the Dutch planters in 1773 for the military expeditions against the Maroons, described the Maroon rice fields he encountered on his raids and drew detailed maps of the Maroon villages and surrounding fields (Price \& Price, 1992; Carney, 2005). Rice, a seemingly non-existent crop in the plantation economy of Suriname, thus reappeared as a crop of importance in the Maroon communities. Something similar happened for another group of labourers, entering Suriname after the Dutch had abolished slavery. Thousands of recruited workers from (British) India and Java were shipped to Suriname to reinvigorate the ailing plantation economy. Few of the Asian labourers returned home after their contracts ended and the majority settled in Surinam as smallholders. Rice was the most prominent crop on their fields.

3. Carney (2005) expands the argument to Brazil and Suriname. 
The re-creation of rice cultivation practices by the Maroon and Asian communities was to establish more resilient livelihoods in general. By doing so, these communities provided, indirectly, a message to the Dutch colonizers that their ambitions to shape the agrarian landscape as a patchwork of large plantations was not the kind of production system they were willing to engage with. The Maroon settlements and Asian smallholder farms thus can be seen as subversive alterations in response to processes of commodification promoted and implemented by the Dutch colonial rule and their associated commercial enterprises. Rather than an act of protest, the rice farms represented a more enduring form of production and action in opposition to the plantation economy, captured by the notion of the anti-commodity (Maat \& Hazareesing, 2016). Rice is typically a crop that can appear as both commodity and anti-commodity within the same region (Maat, 2015, 2016; Richards, 2016). In Suriname, rice shifted to commodity production as the Asian farmers produced considerable surplus rice and the colonial administration started facilitating the production and marketing of rice.

The Maroons and Asian labourers created a social fabric in and around which local networks established, facilitating interconnected global and local circulations of rice. Although there is scant written evidence, in particular for the activities of Maroons, these local networks extended towards neighbouring countries. Early plantation and Maroon settlements were more towards the east, connecting into French Guiana, whereas the Asian rice farmers settled in the Western coastal zone, neighbouring British Guiana. From the early twentieth century, the British and Dutch also started to exchange plant material and knowledge through scientific networks. As these networks expanded to the British and Dutch overseas territories and also connected to other nations, there was a steady inflow of new rice types into Surinam. Halfway the twentieth century the overlapping scientific and trade networks worked towards the same goal of pushing rice into a major export crop. Rice produced in Suriname became a major global commodity, facilitated by the continuous support of the Dutch government. This new phase of rice production largely overshadowed the continuous rice growing activities of the Maroons.

\section{RICE ON PLANTATIONS AND MAROON FIELDS}

The plantation economy of Suriname was primarily run by the West Indies Company (WIC), created in 1621. The Dutch government granted the WIC the exclusive rights to trade slaves from West Africa to the Americas and the company controlled most planta- 
tions of Suriname $e^{4}$. All plantations faced similar challenges regarding food provision. The harsh and violent plantation regime may suggest that plantation owners were rather indifferent about what the slaves were eating. This seems to be confirmed by the fact that slaves were allowed to grow their own food on small plots. However, the authorities made several regulations for food production, primarily for security reasons, because enough food of some quality implied the prevention of food riots. There were rules for plantation owners about which percentage of the field had to be reserved for food crops. On coffee plantations, banana trees had a double purpose as food crop and shade crop for the coffee shrubs. Fishing and hunting formed important additional food sources (Oostindie, 2011; Stipriaan, 1991). There is some evidence that rice was grown on plantations, at least in small quantities, from writings of Herlein in 1718 and the Swedish botanist Rolander in 1755 (Andel, Maas \& Dobreff, 2012).

\section{TABLE 1}

Slaves and Maroons in Suriname

\begin{tabular}{lr}
\hline Number of slaves disembarked in Suriname (1650-1850s) & $\mathbf{2 5 9 , 0 1 3}$ \\
Total number of Maroons estimated in 1900 & 9,600 \\
\hline Number of Maroons by community estimated in 1900 & $-4,000$ \\
Ndyuka (Djoeka) or Aucan & $-4,000$ \\
Saramaka (Saramacca) & -600 \\
Matawai (Matoeari) & -400 \\
Aluku & -400 \\
Paramaka & -200 \\
Kwinti & \\
\hline
\end{tabular}

Total number of Maroons estimated in 1960

$36,500-46,500$

Sources: disembarked slaves taken from http://www.slavevoyages.org/voyage/search, by entering Suriname in the search categories voyage itinerary and principal place of slave landing. [Accessed: 26/05/2017]. Numbers of Maroons taken from Price (2002).

The agricultural dimensions of the transatlantic slave trade have received attention from a variety of scholars, describing the transfer of specific crops, cultivars and related agronomic skills from Africa to the New World (Carney \& Rosomoff, 2009). New crop introductions are not merely a matter of transfer and distribution. Besides the importance of similarity in climatic and ecological factors, such as soil conditions and disease resistance, a successful introduction of a crop to a new place requires a favourable social structure. As discussed in the previous section, in some locations in the Americas the colonizers turned rice into a plantation crop, for which the knowledge and skills of the slaves orig-

4. Until 1815 the Dutch also controlled Essequebo, Demerary and Berbice, after that year British Guiana and now Guyana. 
inating from rice-growing areas in West Africa was likely an important factor. However, in the African context, the interplay between climate, ecology and social structures is far from uniform. Rice is a plant with many different cultivated types, with specific varieties carefully selected by farmers for certain topographical zones, for particular seasons and labour availability throughout the year. Except for some coastal and swamp areas, most rice cultivation in Africa is located in forest areas, using "slash and burn" or shifting cultivation techniques (Richards, 1986). Transferring one particular rice type from one place to another will result in much lower yields or no harvest at all unless time is invested in sorting out the right combination of types of rice, fields and crop management. Within the plantation economy of Suriname the slaves were hardly given the time or space to practice shifting cultivation. That was different for the Maroons.

Marronage was a widespread phenomenon in Suriname. Several Maroon groups settled in the forest interior, the two largest being the Aucans and the Saramaccans (Table 1). The Dutch plantation owners organised military expeditions to trace and destroy the Maroon settlements in the forested interior of Suriname, but these expeditions were overall ineffective. To reach Maroon settlements the militias used recaptured Maroons as guides, who often misled the soldiers or signalled their arrival so that the people could escape into the forest or set up an ambush. Moreover, the militias used slaves to carry food, weapons and ammunition, many of them escaping in the turmoil of the assaults. Reversely, Maroons often attacked plantations to seize goods and liberate slaves. The Dutch ultimately changed their strategy from military repression to peace negotiations (Groot, 1985; Muller, 1973). The written sources about the Maroon communities in the eighteenth century stem from the logs and other writings about the military encounters. Rice fields are frequently mentioned, showing the importance of this crop for the Maroons.

More detailed accounts of the rice fields and rice culture of the Maroons are provided in the twentieth century. Agronomists became interested in the crops grown by these communities and in later decades anthropologist went to study the Maroons. The works of Richard and Sally Price provide detailed information about all aspects of Maroon life, including agricultural practices, the social organisation and rituals connected to these practices and food culture. Their observations show that the Maroon rice farmers are mainly women, with a skilled eye to distinguish and order various different rice varieties.

I have elicited the names of seventy-four varieties (of which many have multiple names and twenty are further divided into named sub-varieties), but because I still encounter new varieties each time I ask, I have no reason to believe I have even approached a complete list. Each variety is classified as "red" or "white" (depending on the darkness of its grains), and associated with details of its appearance, the time 
it takes to ripen, the difficulty with which it is hulled, and the history of its introduction to the region (Price, 1993: 31).

In recent years Tinde van Andel and her team have collected several rice varieties among Maroon communities with a closer eye on the botanical features. This confirms the richness of the Maroon rice practices and the cultural importance of specific varieties (see Table 2). Remarkably, one of the collected samples is a variety of African rice (Oryza glaberrima), a species that is only grown in Africa (Andel, 2010; Andel et al., 2016). Given the few written sources, reconstructing the history of the Maroons through the genetic diversity of their crops seems an interesting road ahead to analyse the origins of the Suriname rice gene pool.

The sporadic mentioning of rice on the slave plantations and the presence of glaberrima rice suggest that there was a minor and perhaps suppressed cultivation of rice on the plantation until about the 1800 s and 1810 s. Slaves may have grown rice secretly, "hidden" between other crops or in small plots that were neither illegal nor considered worth mentioning in the plantation's bookkeeping. However, the kind of shifting cultivation practices, typically for African rice cultivation, certainly were not allowed by the colonial authorities. Only when escaping in the forest could such practices be taken up and that is what Maroons did. The Maroon rice, therefore, is an example of a crop that played an important role in the resistance against the slave-based plantation economy. This form of production and the significance of the rice crop mean that Maroon rice was an anti-commodity (Maat, 2015; Richards, 2016).

In Suriname, like in other countries in the Americas, rice gained in significance as a food crop and as a commercial crop during the nineteenth century. The anti-commodity notion does not exclude the emergence of local markets or other forms of exchange of products and Maroons certainly exchanged rice within their communities and possibly between communities. A publication from the 1930s, written by agronomists in British Guiana, opens with a short history of rice mentioning that the colonial government considered, in 1810, to send a special expedition to destroy rice fields of runaway slaves because they were growing rice in large quantities (Codd \& Peterkin, 1933). The authors do not say what motives the government had but most likely they tried to exclude the Maroons from participation in the local food economy. With the growth of the labour force and population in general, the demand for food also increased. Some plantation owners experimented with rice as a commercial crop. In 1853 a company in Georgetown planted 150 acres of rice at a plantation called Vive la Force on the edges of the Demerara river, but the results were not encouraging (Codd \& Peterkin, 1933). In Suriname some plantations did similar experiments. This may have been triggered by the commercial success 
of rice in the USA and other countries in the region. Suriname planters occasionally bought shiploads of rice from these countries (Stipriaan, 1991:374). These new regional networks in which rice circulated as a commodity co-emerged from increasing demands for food in Suriname and other countries in the region and an overall shift in the world market for rice.

\section{THE CIRCULATION OF CAROLINA RICE}

Rice is known by Europeans as a valuable food item for many centuries. Substantial supply came from Italy, a major producer since the sixteenth century and exporting to most European countries, including the Netherlands (Alfani, 2010). By the eighteenth century the largest share of European rice imports came from the slave-based rice plantations in South Carolina and Georgia. From the beginning of the nineteenth century, the colonial territories in Asia overtook the Carolina plantations as main supplier for the European market. European consumers were used to Italian and Carolina rice. The types of rice grown in these regions were of the japonica type, a subspecies of Oryza sativa that has bolder grains and grows well in more temperate climates and is less susceptible for fluctuations in daylight ${ }^{5}$. The Italian varieties and even more so Carolina rice had bigger grains compared to most Asian varieties. Because European consumers liked this type of rice and to meet the increasing European demand, colonial administrators in Asia made several attempts to set up production of Carolina rice in Asia. The Dutch experimented with the variety on Java and the British did the same in India (Anonymous, 1879). There are several colonial reports from the second half of the nineteenth century that talk about experiments with Carolina paddy or gold seed. The Europeans never succeeded but did select Asian varieties with similar characteristics, often labelled as export rice, mostly grown on a contract basis by Asian rice farmers for European companies that shipped the rice to Europe.

The importance of the Carolina rice plantations for the global rice markets dwindled in the nineteenth century but its importance continued in different ways. First of all, the Carolina rice plantations offered a commercial production model. Although the form of production itself, characterised by lowland fields worked by slaves, appeared hard to copy, and no longer an option after the abolishment of slavery, the European demand for rice, impossible to be fulfilled by Italy alone, made the European colonizers look for other ways to grow rice on a commercial scale. The Asian colonies, in particular India, Burma and

5. The Carolina rice is most likely a tropical japonica, probably originating from South-East Asia after a likely "stop-over" in Madagascar. 
Java dominated commercial production of rice for foreign markets (Coclanis, 1993; Maat, 2015). A second effect of the early success of Carolina rice was an increased interest in rice varieties. The specific and commercially attractive grain size of Carolina gold spurred colonial officials and the increasingly better informed agricultural experts to look for similar varieties and test them in different places of the colonial networks.

With the emergence of colonial plant breeding, during the early twentieth century, this interest was turned into extensive breeding programmes and field experiments with rice. The colonial administrations and agronomist gradually became the major actors in reshaping the global networks in which rice was circulated. Besides a commercial model for rice production, Carolina rice created a breeding model for rice improvement, obviously with commercial production as an underlying motive. By the early twentieth century the Dutch agronomists in Suriname worked on ways to stimulate rice cultivation among smallholders in the coastal lowlands. A variety they considered most promising for further selection and distribution was called Skrivimankoti. This variety circulated in the expert networks across the globe. One place it was sent to was the US Department of Agriculture. In the agricultural report of 1906 the Dutch underline the potential of Skrivimankoti by quoting the response they received from USDA pathologists Haven Metcalf:

\section{One sample of rice has arrived, namely the Skrivimankoti. I am very much interested in this rice as it seems to be not only a gold rice, but also large grained and of high quality. It is indeed more like our Carolina Golden than any for- eign rice that I have yet seen ${ }^{6}$.}

The Skrivimankoti rice was also sent to Java where the Dutch agronomist and pioneer in rice breeding Van der Stok underlined the potential of the variety for Java (Maat, 2001). Another important connection for the Dutch agronomists in Suriname was with neighbouring British Guiana, where agronomists worked on rice improvement in very similar ways. The Dutch agronomist Boonacker visited Demerara in 1906 and reported that the main variety grown there, called Creole rice or Demerara Creole, was very similar to Skrivimankoti.

The knowledge about rice varieties and the mechanisms of reproduction and heredity were still in its infancy in those years. Although theories of plant reproduction, most notably Mendel's laws, were known to the agronomist, control over the reproduction of the minuscule rice flowers was technically complicated. Moreover, given the many dif-

6. Retrieved from the 1907 report of the Inspector for Agriculture in the West Indies (Inspectie van den Landbouw in West-Indië). 
ferent rice types, getting an overview of all the available material and its characteristics was very time consuming. Until the 1930s most of the rice breeding implied the selection of rice phenotypes and testing them under different conditions, very similar to what farmers have been doing for centuries (Maat, 2001; 2008). Skrivimankoti, the lookalike of Carolina rice, served as a phenotypic orientation for the agronomists.

TABLE 2

List of rice types present in different communities, illustrating the diversity of the rice gene pool in Suriname ${ }^{\star}$

Rice types collected by colonial agronomists in the period 1900-1940

\begin{tabular}{llll}
$\begin{array}{l}\text { Collected in or attributed } \\
\text { to Maroon communities }\end{array}$ & $\begin{array}{l}\text { Collected in or attributed } \\
\text { to Indian communities }\end{array}$ & $\begin{array}{l}\text { Collected in or attributed } \\
\text { to Javanese communities }\end{array}$ & $\begin{array}{l}\text { Exchanged among experts, } \\
\text { most acquired from Indonesia }\end{array}$ \\
Bruin missie & Skrivimankoti & Gebang & Tjereh (tjempoh weldoet) \\
Witte areisi & Anaki tapoen & Kontoelan & Boeloeh poetih \\
Blaka areisi & Fini tére & Metakwangen & Boeloe itam \\
Wanica rijst (brown and white) & Andoe-manis & Tjere \\
Mooi missie & Ketan hitam (glutenous) & Kindja ranteh, \\
Aloekoe & & Ketan hitam (glutenous) \\
\hline
\end{tabular}

Rice types collected and reported by Van Andel in 2013

Collected in Aucan Maroon communities

Baaka alisi Lebi alisi

Akowina futu Lebi mesti alisi

Asikasiri Lebi sowla alisi

Blaka tere saka Moimasra, alulu

Gaan lebi alisi Pikin lebi alisi

Gaan weti alisi

Kwaka alisi
Collected in Saramaccan Maroon communities

Baáka alísi, mátú alísi Padi alesi

Bee alisi Pikin weti alisi

Bee kakisi alesi Pikinsii alisi

Blaka tere alisi Potokíi alisi

Djampö alisi Sowla, kuli alisi

Honjo alisi Yesi pèkè alisi

*This is not a complete list or a representative sample.

Source: colonial literature and collected material by second author.

The colonial agricultural reports of Suriname of the years 1904 until 1907 report about eight different upland varieties and thirteen lowland varieties received from Demerara and four lowland varieties from Java. These were all tested out in fields on the plantations Rust en Werk (Rest and Work), Berlijn (Berlin) and fohannesburg. However, none of these outperformed the Skrivimankoti ${ }^{7}$. Despite their positive assessment and sharing the variety with experts elsewhere, Skrivimankoti nor Demerara Creole had arrived in the region

7. Retrieved from the 1904 report of the Inspector for Agriculture in the West Indies (Inspectie van den Landbouw in West-Indië). 
through these experts networks. The source is most likely the contract labourers from Asia that were recruited to work on the plantations. These were a third group, besides the agronomist and the Maroons, actively selecting rice. Table 2 gives an indication of the complexity of the rice gene pool in Suriname. Some of the names of the Marroon collection from 2013, for example padi aleisi (paddy rice) and kuli alisi (coolie rice), represent the distribution of rice types within local exchange networks and acculturation of varieties by different groups.

\section{ASIAN RICE IN THE GUIANAS}

With the recruitment of labourers from India and Indonesia, the colonial government tried to revive the crumbling plantation economy in Surinam. Most sugar plantations failed to compete with the larger and industrialised cane sector in other parts of the Caribbean. There were short-lived experiments with cocoa and banana plantations. A gradually decreasing number of plantations survived with the cheap Asian workforce. The first ship with Indian contract labourers, mostly men but also women, arrived in 1873 and from 1890 labourers from Java arrived to work on the plantations. The Indian labourers were primarily recruited from the northwest of India (the area today forming the states of Uttar Pradesh, Uttarakhand and Bihar) a process that lasted until 1916. A total of 34,304 Indian labourers were shipped to Suriname in that period (Hoefte, 1998). The total of Javanese labour migrants brought to Suriname was 32,956 in the period between 18901940 (Hoefte, 1998). Most labourers were recruited on the basis of a three-year contract. At the end of their contract period some labourers returned to their home country but most of the Asian labourers continued farming in Suriname, stimulated by the colonial government through a land allocation regulation. Like the African slaves before them, the recruited labourers from India and Java took seeds, fruits or other plant material with them. The labourers from India, known as Hindustani in Suriname, and the Javanese each maintained their own customs and routines. Most families had one or more rice fields. The colonial Department of Agriculture, created in Suriname in 1904 started monitoring the Asian smallholders and noted their success in rice farming.

The colonial administration estimated that total rice production in 1904 was 800 metric tons, increasing to 2,000 in 1910 and over 12,000 tons in the early 1920s (Stahel, 1933). In the 1900s the Department started to support rice farming by bringing new rice varieties to Suriname. In 1933 the agronomist Stahel, Director of agricultural research from 1919, wrote an overview of the rice improvement activities of the Department. He recalled the first acquisitions from Java and Demerara in 1904, followed by new batches being sent in 1907 and 1911, including seeds from India and French Indochina (Viet- 
nam). These varieties were tested on fields in the various districts of Suriname. Stahel remarks that most of these varieties did not perform very well on the heavy clay soils in the coastal districts. The varieties that performed well and were appreciated by the farmers were reproduced and distributed. The departmental reports mention that smallholders originating from India had different preferences than the rice farmers who had their roots in Java. In the 1911 report the agronomist Drent mentions several varieties popular among the Javanese, all having Javanese sounding names: Kindja ranteh, Ketan hitam, Tjereh, Boeloeh poetih and Boeloe itam (see also Table 2). He added that because the Boeloeh poetih was a popular variety, the department decided to multiply the variety on a field of the plantation Guineesche-Vriendschap (Guinean Friendship).

The name of the apparently preferred variety Boeloeh poetih indicates this was a javanica type. The two main cultivated subspecies or varietal groups of Asian rice (Oryza sativa) are indica and japonica. The japonica rices perform well in areas further away from the equator. In Indonesia a morphologically distinct group of japonica rice exists, in modern taxonomy referred to as tropical japonicas but also known as javanica or bulu (Vaughan, Lu, \& Tomooka, 2008). The latter name (in the Dutch colonial spelling boeloe or boeloeh, pronounced as bulu in English) is the original Javanese name for these rice types. The bulus can be morphologically distinguished from indica by the long awns (a bristle on the chaf). Other characteristics of the bulus are lower sensitivity for drought and daylight variation. The varieties usually have a longer growth period, the time between sowing and ripening. These characteristics together made the variety of interest to farmers because it provided more flexibility in planting and harvesting time. On Java there were many different bulu varieties available to farmers (Maat, 2008; Eng, 1994). The preference of the Javanese farmers in Suriname, as reported by Drent in 1911 thus comes as no surprise. These farmers had experience with these varieties and knew how to use and select varieties in light of the specific conditions of soil, climate, weeds and pests.

The smallholders from India, who had arrived in Suriname before the Javanese, brought similar knowledge and skills to the country. Moreover, it is likely that there were interactions and exchanges with labourers in British Guiana. Not only was the abolition of slavery in the British colonial territories effectuated many years before the Dutch did the same, the English also started earlier with the transport of indentured labourers to the Caribbean, including British Guiana (Hoefte, 2012). The earlier mentioned similarity between the varieties Demerara Creole and Skrivimankoti makes clear that they not only grew rice but selected varieties in very similar ways. From the various descriptions of Skrivimankoti it is most likely an indica variety. The Hindustani called it Djerehi and was grouped under the category of it patarka dhân (slender rice), referring to the long and 
thin grains and preferred by the Hindustani population. The Dutch agronomists testing the variety alongside others noted that it had the best yield but was very vulnerable to drought ${ }^{8}$. The other popular varieties in Surinam, Wanica and Bruin Missie (see Table 2), originating from the Maroon fields, had lower yields but were much more tolerant for dry periods. The fields where the Hindustani farmers grew rice were generally better located in terms of water availability.

The colonial experts were aware of the importance of proper water management to improve the performance of rice in paddy fields. For that reason the main focus in the early decades of the twentieth century was on the selection of varieties performing well in wet conditions alongside measures to improve irrigation and drainage. The rather successful introduction of wet rice production in the coastal zone of Suriname was an unintended effect of the recruited Asian labourers for the plantation economy. The choice of most Asian labourers not to renew their contracts on the plantations nor returning home and to continue as smallholder rice farmers must have been the best, or probably the least worst option they had. They managed to turn Suriname from a net rice importing country into a rice exporter by the end of the 1910s. Like for the Maroons, growing rice had cultural significance for the Asian labourers. But contrary to rice cultivation of the Maroon communities, the colonial government supported the Asian labourers in growing rice. In other words, rice grown by the Maroons as anti-commodity was complemented by rice grown by Asian farmers as commodity, initially circulating in the local food economy but soon becoming part of global trade networks.

\section{GREEN REVOLUTION RICE}

A last phase in the creation of a Surinamese rice gene pool came with the emergence of a large mechanised rice scheme in the Nickerie district. Despite the success of Asian rice farmers, the Dutch administrators thought that European farmers were better in growing rice. Based on a failed experiment with mechanised rice in the Netherlands Indies in the late 1910s, the idea was to try again in Suriname with Dutch farmers. In 1922 the repatriated sugar manufacturer Pyttersen sent a report to the Dutch government about the options for mechanised agriculture. Pyttersen considered mechanisation of sugarcane farming more profitable than rice but the government pushed through. In 1933 they contracted the Van Dijk company to develop a rice polder using machinery for the various farm operations. The company also initiated selection and crossing of rice types, suitable

8. Retrieved from the 1907 report of the Inspector for Agriculture in the West Indies (Inspectie van den Landbouw in West-Indië). 
for mechanical operations. After six years experimenting the company calculated that a positive net balance could be achieved when the experiment was scaled up.

After the Second World War the Dutch government initiated a more structural investment plan for the Surinamese economy. In 1949 the government created a fund to finance a semi-private company called the Stichting Machinale Landbouw (Machine Agriculture Foundation, hereafter SML). In 1950 the SML initiated the implementation of rice polders, starting with an experimental polder of 200 hectares, followed by the construction of several polders of 5,000 hectares each. Science had a leading role in the SML. Most experts in water management, soil improvement, agricultural machinery and crop improvement were recruited from the agricultural college in Wageningen (Maat, 2001). In 1951 an experimental station for rice breeding was created, staffed by J. J. Mastenbroek and J. G. J. van der Meulen, both experienced rice breeders arriving from the Netherlands Indies ${ }^{9}$. They continued with the selection work done by the Van Dijk company. A selected line from a spontaneous cross between Rexoro, a variety introduced from the USA, and a local selection named D79, resulted in a variety named Aurora. The Van Dijk company worked alongside the SML breeders and crossed both Aurora and Rexoro with Skrivimankoti. The joined efforts are reflected in some variety names, most prominently Dima, a contraction of the names Van Dijk and Mastenbroek (see Figure 1).

The rice breeding strategy of the Green Revolution arrived first in Suriname through the person of Van der Meulen. He had been leading the breeding station on Java where he had worked on crossings between indica and javanica varieties. By and large, indica varieties have a shorter growth period whereas javanica was less susceptible to daylight variation and responded better to fertiliser. These characteristics together were important to breed varieties that could be grown in different conditions. One of the successful lines of Van der Meulen's breeding work, called Peta, was later used by te breeders of the International Rice Research Institute at the Philippines who, besides the mentioned characteristics added the "dwarfing" or short-straw characteristic to the breeding goals (Barker, Herdt \& Rose, 1985). Van der Meulen brought seed of about 19 Indonesian varieties to Suriname, which did not perform very well at the SML station but two other Indonesian varieties, Bengawan and Mas, appeared promising. Furthermore, the SML breeders tested over ninety varieties originating from British Guiana, Italy and the USA. In 1966 the leading plant breeder at SML, Van den Bogaert, integrated the SML and

9. In the Netherlands Indies an anti-colonial movement, politically active from the 1900s, declared independence in 1945 after Japanese troops were forced out by the US and British armies, resulting in the independent Republic of Indonesia in 1949. All Europeans employed by former the colonial administration were expelled. Suriname was not affected by the war nor had a strong independence movement. The country became independent as late as 1975 . 
Green Revolution breeding strategies. Under his guidance growth duration of SML varieties was reduced from 150 to 100 days and straw length from more than 1.5 meter to less than 1 meter. In following years more IRRI varieties were used in the SML breeding activities (Figure 1).

\section{FIGURE 1}

Origins of the SML rice varieties*

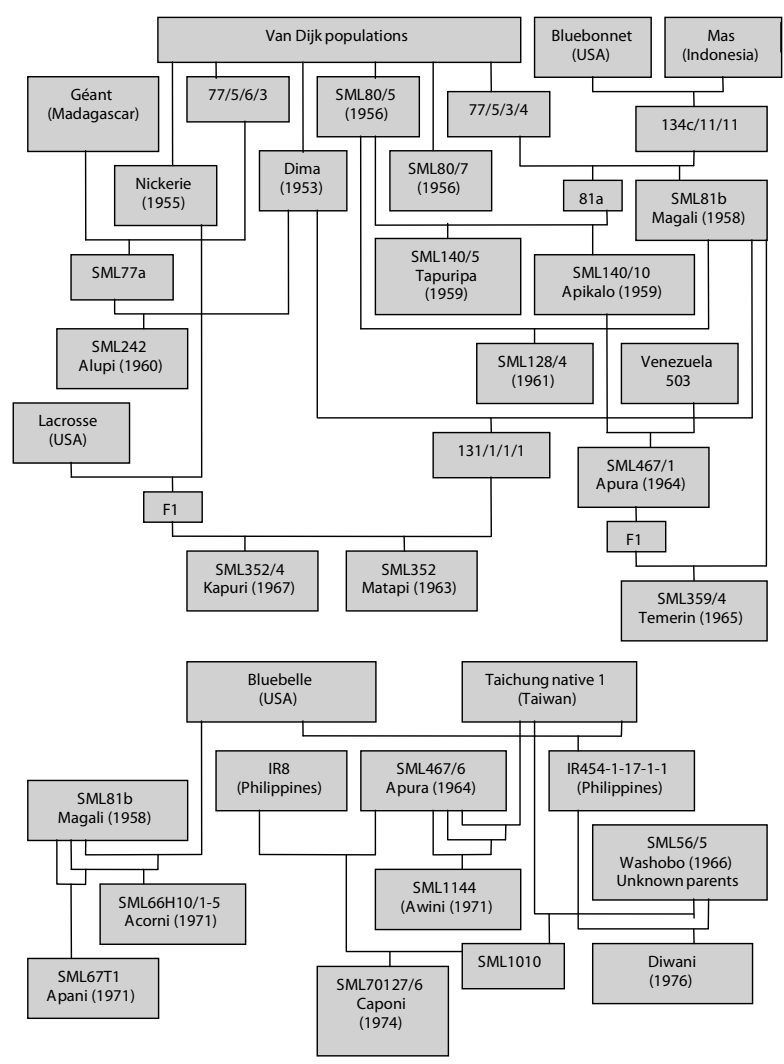

*A U-shaped or L-shaped line indicates a crossing between two varieties; a straight line down indicates a variety selected from offspring from a crossing or from a collection.

Source: Maat (2001).

From 1960 the SML started to extend its technologies to the smallholder farmers in the region, mainly by offering them cheap seed of the SML varieties. The characteristics of the SML varieties were not liked very much by the smallholders. The firm, inflexible stems of the SML varieties easily broke when transplanting young seedlings and the SML varieties grew relatively slowly in the first weeks, increasing sensitivity to weeds and pests. The smallholder rice growers continued to use Skrivimankoti and a variety introduced 
from British Guiana. The Dutch tried to convince the smallholders by offering cheap inputs (fertiliser and pesticides) and free mechanised harvesting when export quality standards were met. Over the years the mechanised SML farming methods and the methods of the smallholder rice farmers merged into a form of semi-mechanised rice cultivation that now dominates the coastal zone of Surinam.

\section{CONCLUSION}

Suriname, a small country in South America, has built up a pool of genetic material of rice, based on colonial activities in different periods. These colonial activities all focused on commercial production for global markets. Although the rice gene pool in Suriname is largely a product of the colonial commercial activities, it would be too simple to attribute all agency to the Dutch and other European colonizers. In fact, many of the rice types arrived in Suriname despite or even contrary to commercial intentions of the colonizers. The rice cultivation practices of the Maroon communities are emblematic for the resistance against the cruel slave-based planation economy. These Maroon groups have taken up rice cultivation in their villages, something they were not allowed to or were given no time for when living on the plantations.

Like the Maroons before them, the Asian labour recruits were not voluntarily engaging in commercial agriculture for the global market. However, they were freer than the slaves to build up a livelihood of their own preference. After their contracts ended, most of them took up rice cultivation as their main source of food and income. The Asian migrant labourers had brought rice seeds with them and cultivated rice on the farms they set up in the coastal wetlands. The rapidly expanding rice sector in this area produced enough surplus rice for export. The colonial government acknowledged the importance of rice and included the crop in their plans to revive commercial agriculture. The anticommodity rice production of the Maroons was soon overshadowed by the commodity rice production of the Asian farmers, transforming the agricultural sector of Suriname and its role in the global market. Based on this commercial success, a second transition was set in motion, creating a leading role for science in the further improvement and expansion of commercial rice farming. The semi-private rice company SML pushed commercial rice production to a new phase, creating a form of high-tech rice production that, although never cost-effective without government support, turned the coastal rice zone into a major rice growing area that still exists today.

The history of rice in Suriname provides a new perspective on the role of commercial networks and global markets. Although the capacity to ship people and goods across 
the oceans is a necessary condition to establish frequent connections between countries in faraway continents, the terms of commercial enterprise did not fully dictate agricultural production in the colony. The practical knowledge of slaves and indentured labourers appeared as an important factor, alongside commercial production and scientific knowledge. In light of present-day concerns over genetic resources and sustainable agriculture, the experiences and the many rice varieties grown on fields of different communities in Suriname require further analysis and wider appreciation.

\section{ACKNOWLEDGEMENTS}

We thank the reviewers, editors of Historia Agraria and Jon Harwood for their valuable comments. Our thanks also go to Paul Richards for his monumental knowledge of African rice farming and for proposing the anti-commodity concept. The Anne van Dijk Rice research Centre Nickerie (ADRON) in Suriname has been very supportive since we started exploring the history and diversity of rice in the country. Our thanks particularly go to Jerry R. Tjoe Awie, coordinator of ADRON's rice breeding programme.

\section{REFERENCES}

Alfani, G. (2010). Climate, Population and Famine in Northern Italy: General Tendencies and Malthusian Crisis, ca. 1450-1800. Annales de démographie historique, 2 (120), 23-53.

ANDEL, T.van (2010). African Rice (Oryza glaberrima Steud.): Lost Crop of the Enslaved Africans discovered in Suriname. Economic Botany, 64 (1), 1-10.

Andel, T. van, MAas, P. \& DobrefF, J. (2012). Ethnobotanical Notes from Daniel Rolander's Diarium Surinamicum (1754-1756): Are these Plants still used in Suriname Today? Taxon, 61 (4), 852-63.

Andel, T. van, Meyer, R. S., Aflitos, S. A., Carney, J. A., Veltman, M. A., Copetti, D., Flowers, J. M., Havinga, R. M., MaAt, H., Purugganan, M. D., Wing, R. A. \& Schranz, M. E. (2016). Tracing Ancestor Rice of Suriname Maroons back to its African Origin. Nature Plants, 2 (16149).

ANONYMous (1879). Proeven met Carolina padi genomen in het presidentschap Madras.

Tijdschrift voor Nijverheid en Landbouw, (24), 263-81

Arnold, D. (2005). Europe, Technology, and Colonialism in the $20^{\text {th }}$ Century. History and Technology, 21 (1), 85-106.

Barker, R., Herdt, R. W. \& Rose, B. (1985). The Rice Economy of Asia. Washington, DC:

Resources for the Future. 
Carney, J. A. (2001). Black Rice: The African Origins of Rice Cultivation in the Americas. Cambridge: Harvard University Press.

Carney, J. A. (2005). Rice and Memory in the Age of Enslavement: Atlantic Passages to Suriname. Slavery \& Abolition, 26 (3), 325-47.

Carney, J. A. \& Rosomoff, R. N. (2009). In the Shadow of Slavery: Africa's Botanical Legacy in the Atlantic World. Berkeley: University of California Press.

Coclanis, P. A. (1993). Distant Thunder: The Creation of a World Market in Rice and the Transformations It Wrought. The American Historical Review, 98 (4), 1050-78.

Codd, L. E. W. \& Peterkin, E. M. (1933). Rice in British Guiana, 1927-1932. Georgetown: British Guiana Department of Agriculture. [Rice bulletin, 1].

ENG, P. VAN DER (1994). Development of Seed-Fertilizer Technology in Indonesian Rice Agriculture. Agricultural History, (68), 20-53.

Fields-Black, E. L. (2008). Deep Roots: Rice Farmers in West Africa and the African Diaspora. Bloomington: Indiana University Press.

Groot, S. W. DE (1985). A Comparison between the History of Maroon Communities in Surinam and Jamaica. Slavery \& Abolition, 6 (3), 173-84.

Hawthorne, W. (2015). The Cultural Meaning of Work: The "Black Rice Debate" reconsidered. In E. L. FieldS-Black, F. BRAY, D. SCHÄFER \& P. CoClanis (Eds.), Rice: Global Networks, New Histories (pp. 279-90). New York: Cambridge University Press.

Headrick, D. R. (1988). The Tentacles of Progress: Technology Transfer in the Age of Imperialism, 1850-1940. New York/Oxford: Oxford University Press.

Hilbert, L., Neves, E. G., Pugliese, F., Whitney, B. S., Shock, M., Veasey, E., ZimPEL, C. A. \& Iriarte, J. (2017). Evidence for Mid-Holocene Rice Domestication in the Americas. Nature Ecology \& Evolution, 1(11), 1693-98.

Hoefte, R. (1998). In Place of Slavery: A Social History of British Indian and Favanese Laborers in Suriname. Gainesville: University Press of Florida.

Hoefte, R. (2012). Plantations and Labour in the Caribbean in the Long Nineteenth Century. International Review of Social History, 57 (2), 257-68.

LAw, J. (1986). On the Methods of Long-Distance Control:Vessels, Navigation, and the Portuguese Route to India. In J. Law (Ed.), Power, Action and Belief: A Nerw Sociology of Knowledge? (pp. 234-63). London: Routledge \& Kegan Paul.

MaAt, H. (2001). Science Cultivating Practice: A History of Agricultural Science in the Netherlands and its Colonies, 1863-1986. Dordrecht: Kluwer Academic Publishers.

MAAT, H. (2008). Agriculture in Indonesia. In H. SELIN (Ed.), Encyclopaedia of the History of Science, Technology, and Medicine in Non-Western Cultures (pp. 1-5). Dordrecht: Springer Netherlands.

MAAT, H. (2015). Commodities and Anti-Commodities: Rice on Sumatra 1915-1925. In E. L. Fields-Black, F. BraY, D. SChÄFER \& P. Coclanis (Eds.), Rice: Global Networks, New Histories (pp. 335-54). New York: Cambridge University Press. 
MaAT, H. (2016). Upland and Lowland Rice in the Netherlands Indies. In S. HazAREESINGH \& H. MAAT (Eds.), Local Subversions of Colonial Cultures: Commodities and Anti-Commodities in Global History (pp. 49-69). London: Palgrave MacMillan.

MaAT. H. \& HAZAREesing, S. (2016). Introduction. In S. HAZAREeSINGH \& H. MAat (Eds.), Local Subversions of Colonial Cultures: Commodities and Anti-Commodities in Global History (pp. 1-9). London: Palgrave MacMillan.

Martínez, C. P. et al. (2014). Rice Breeding in Latin America. Plant Breeding Revierws, (38), 187-277.

Mauser, B. L., Nuijten, E., Okry, F. \& Richards, P. (2015). Red and White Rice in the Vicinity of Sierra Leone: Linked Histories of Slavery, Emancipation, and Seed Selection. In E. L. Fields-Black, F. BRAY, D. SchäFer \& P. Coclanis (Eds.), Rice: Global Networks, New Histories (pp. 138-62). New York: Cambridge University Press.

Muller, M. (1973). Tien jaren Surinaamse guerilla en slavenopstanden, 1750-1759. Tijdschrift voor Geschiedenis, (86), 21-50.

Oostindie, G. (2011). Slave Resistance, Colour Lines, and the Impact of the French and Haitian Revolutions in Curaçao. In W. KLooster \& G. Oostindie (Eds.), Curaçao in the Age of Revolutions, 1795-1800 (pp. 1-22). Leiden: KITLV Press.

Pereira, J. A. \& Guimarães, E. P. (2010). History of Rice in Latin America. In S. D. Sharma (Ed.), Rice: Origin, Antiquity and History (pp. 432-51). Enfield: Science Publishers.

PrICE, R. (2002). Maroons in Suriname and Guyane: How Many and Where. New West Indian Guide/Nieuwe West-Indische Gids, 76 (1-2), 81-8.

PRICE, R. \& PRICE, S. (Eds.) (1992). Stedman's Surinam: Life in an Eighteenth-Century Slave Society: An Abridged, Modernized Edition of Narrative of a Five Years Expedition, against the Revolted Negroes of Surinam. Baltimore: Johns Hopkins University Press.

Price, S. (1993). Co-Wives and Calabashes. Ann Arbor: University of Michigan Press. Richards, P. (1986). Coping with Hunger: Hazard and Experiment in an African RiceFarming System. London: Allen \& Unwin.

Richards, P. (2016). Rice as Commodity and Anti-Commodity. In S. HAZAREESINGH \& H. MAAT (Eds.), Local Subversions of Colonial Cultures: Commodities and Anti-commodities in Global History (pp. 10-28). London: Palgrave MacMillan.

RoBERTS, L. (2009). Situating Science in Global History: Local Exchanges and Networks of Circulation. Itinerario, 33 (1), 9-30.

SMITH, H. R. (2012). Rich Swamps and Rice Grounds:The Specialization of Inland Rice Culture in the South Carolina Lowcountry, 1670-1861. PhD dissertation. University of Georgia.

STAHEL, G. (1933). De rijstcultuur in Suriname. Mededelingen van het Landbouwproefstation, Suriname, (2). 
STIPRIAAN, A. van (1991). Surinaams Contrast: Roofbouw en Overleven in een Caraibische plantage Economie 1750-1863. PhD. dissertation. Vrije Universiteit Amsterdam.

Vaughan, D. A., Lu, B. R. \& Tomooka, N. (2008). The Evolving Story of Rice Evolution. Plant Science, 174 (4), 394-408. 